DOI: https://doi.org/10.24123/jbt.v3i02.2512

\title{
ANALISIS DAMPAK PEMBANGUNAN JALAN TOL MEDAN- TEBING TINGGI TERHADAP KEGIATAN JAJANAN USAHA MIKRO KECIL DAN MENENGAH DI PASAR BENGKEL
}

\author{
Januardin Manullang ${ }^{1}$, Hottua Samosir ${ }^{2}$ \\ ${ }^{1,2}$ Univeristas Prima Indonesia, \\ Email: ${ }^{1}$ januardin.manullang@gmail.com
}

\section{Abstract}

The workshop market has a pretty good potential for "dodol” business. Dodol has become a characteristic of this region so that the demand will remain stable. Sales of dodol, which increases every year, makes this food have a bright prospect to develop because the raw materials for its manufacture are available locally. The purpose of this research is to provide analysis and the impact of existing problems, from a phenomenon due to the opening of a high-cliff-field toll road to economic life and the selling power of snacks and food in small and medium-sized enterprises.Therefore, it is not out of business due to development impacts of high-cliff-field toll road. The importance of carrying out this research was to give a solution and input from the district government as well as the North Sumatra provincial government in the management of small and medium-sized micro enterprises in the workshop market. Type of Research was Case Research (Case Study). The impact of the construction of the Medan-Tebing Tinggi toll road is very important for the MSME community around the workshop market. The impact was not only on the community but also on the regional government.Per capita income from the MSME market workshop decreased dramatically to 50\% of income per month. In addition, fewer workers were employed by MSMEs, where previously they could employ 2 to 5 people per store. Now they can only employ 1 to 2 people. Regional Original Income derived from restitution has significantly dropped since the construction of the toll road. On the other hand, the positive impact felt by the market community is that there was no congestion and the air pollution decreased.

Keywords:Toll road, UMKM/small and medium-sized enterprise,case study. 


\section{Pendahuluan}

Usaha Mikro Kecil dan Menengah mampu bertahan secara makro ekonomi mampu meyangga perekonomian nasional. Hal itu dapat kita lihat dari masa-masa krisis yang terjadi di negeri ini, baik krisis ekonomi tahun 1998 dan 2008. Usaha Mikro Kecil dan Menengah mampu menciptakan lapangan kerja bagi masyarakat banyak dan mampu menjadi alternatif solusi dari masalah kemiskinan. Pasar Bengkel merupakan sebuah pusat jajanan atau Pusat Oleholeh yang ada di kabupaten Serdang Bedagai. Pasar Bengkel berada di kawasan Jalan Lintas Sumatera (Jalinsum), tepatnya di Desa Bengkel, Kecamatan Perbaungan, Serdang Bedagai, Sumatera Utara. Pasar Bengkel juga terkenal dengan sebutan Pasar Dodol. Pasar bengkel telah ada sekitar puluhan tahun yang lalu.

Pasar bengkel memiliki potensi usaha dodol yang cukup bagus. Dodol telah menjadi ciri khas daerah ini sehingga permintaannya akan tetap ada.. Penjualan dodol yang setiap tahunnya meningkat membuat makanan ini memiliki prospek yang cerah untuk dikembangakan karena bahan baku untuk pembuatannya tersedia secara lokal. Penjualan dodol tersebut semakin meningkat sejak adanya pemekaran kabupaten pada tahun 2004 dari Deli Serdang menjadi Serdang Bedagai. Para usahawan juga mengikuti pelatihan mengelola usaha 5 dodol. Pasar bengkel tidak hanya menjual dodol saja, tetapi para pengusaha juga menghiasi tokonya dengan jajanan yang beraneka ragam dan minuman botol yang membuat suasana toko menarik untuk dilihat.

Dari hasil wawancara yang dilakukan oleh peneliti pada beberapa pengusaha yang ada di pasar bengkel sebelum adanya jalan tol Medan-Tebing tinggi, hasil penjualan dodol rata-rata mencapai $20 \mathrm{~kg}$ perharinya. Dengan harga dodol Rp 40.000/kg. Keripik rata-rata 50 bungkus perhari dengan harga Rp. 20.000/3 bungkus sedangkan penjualan dari jam 7 magrib sampai jam 2 subuh sebanyak Rp. 2.000.000 dari berbagai produk. Sedangkan sesudah adanya jalan tol medantebingtinggi penjualan dodol rata-rata penjualan $3 \mathrm{~kg}$ paling banyak dan penjualan kripik hanya rata-rata 3 bungkus per hari dan penjualan semua produk dari jam 7 magrib sampai jam 2 subuh hanya sebesar Rp. 60.000. dan sebanyak kurang lebih 30 tokoh sudah tutup atau gulung tikar.

Adapun rangkuman permasalahan yang dihadapi para usaha mikro kecil dan menengah yang ada di Pasar Bengkel adalah :

1. berkurangnya angkutan pribadi dan umum untuk singgah di pasar bengkel;

2. menurunnya pendapatan sejak adanya jalan tol medan-tebing tinggi;

3. sudah banyaknya para pedagang tutup karena onzet berkurang drastis.

Tujuan penelitiaan ini untuk memberikan analisis dan dampak dari permasalahan yang ada, dari sebuah fenomena karena sudah dibukanya jalan tol medan-tebing tinggi terhadap kehidupan ekonomi dan daya jual jajanan dan makanan yang ada di usaha mikro kecil dan menengah, sehingga tidak gulung tikar karena dampak pembangunan jalan tol medan-tebing tinggi. Pentingnya penelitian ini dilakukan agar ada solusi dan masukan dari pihak pemerintah kabupaten serdang bedagai dan pihak pemerintah provinsi sumatera utara dalam pengelolaan usaha mikro kecil dan menegah yang ada di sekitaran pasar bengkel.

\section{Landasan Teori}

\section{Teori Usaha Mikro Kecil dan Menengah}

Menurut Tambunan (2012 : 11) UMKM adalah unit usaha produktif yang berdiri sendiri, yang dilakukan oleh orang perorangan atau badan usaha di semua sector ekonomi. Pada prinsipnya, pembedaan antara UMI, UK, UM dan UB umumnya didasarkan pada nilai asset awal (tidak termasuk tanah dan bangunan), omset rata-rata per tahun, atau jumlah pekerja tetap. 
Sesuai dengan Undang- Undang Nomor 20 Tahun 2008 tentang Usaha Mikro, Kecil dan Menengah (UMKM):

1) Usaha Mikro adalah usaha produktif milik orang perorangan dan/atau badan usaha perorangan yang memenuhi kriteria Usaha Mikro sebagaimana diatur dalam Undang-Undang ini.

2) Usaha Kecil adalah usaha ekonomi produktif yang berdiri sendiri, yang dilakukan oleh orang perorangan atau badan usaha yang bukan merupakan anak perusahaan atau bukan cabang perusahaan yang dimiliki, dikuasai, atau menjadi bagian baik langsung maupun tidak langsung dari usaha menengah atau usaha besar yang memenuhi kriteria Usaha Kecil sebagaimana dimaksud dalam Undang-Undang ini.

3) Usaha Menengah adalah usaha ekonomi produktif yang berdiri sendiri, yang dilakukan oleh orang perseorangan atau badan usaha yang bukan merupakan anak perusahaan atau cabang perusahaan yang dimiliki, dikuasai, atau menjadi bagian baik langsung maupun tidak langsung dengan Usaha Kecil atau usaha besar dengan jumlah kekayaan bersih atau hasil penjualan tahunan sebagaimana diatur dalam Undang-Undang ini.

Menurut Undang-Undang No. 20 Tahun 2008, pada pasal 6 dijelaskan kriteria-kriteria yang tepat mengenai UMKM.

1. Kriteria Usaha Mikro, ada dua kriteria usaha ini yakni:

a. Memiliki kekayaan bersih maksimal Rp 50.000.000,00 (lima puluh juta rupiah) tidak termasuk tanah dan bangunan tempat usaha; atau

b. Memiliki hasil penjualan tahunan paling banyak Rp 300.000.000,00 (tiga ratus juta rupiah).

2. Kriteria Usaha Kecil. Kriteria usaha ini meliputi:

a. Memiliki kekayaan bersih lebih dari Rp 50.000.000,00 (lima puluh juta rupiah) tidak termasuk tanah dan bangunan tempat usaha; atau

b. Memiliki hasil penjualan tahunan lebih dari Rp 300.000.000,00 (tiga ratus juta rupiah) sampai dengan paling banyak Rp 2.500.000.000,00 (dua miliar lima ratus juta rupiah).

3. Kriteria Usaha Menengah. Ada dua kriteria Usaha Menengah, yaitu:

a. Memiliki kekayaan bersih lebih dari Rp 500.000.000 (lima ratus juta rupiah) sampai dengan paling banyak Rp 10.000.000.000,00 (sepuluh miliar rupiah) tidak termasuk tanah dan bangunan tempat usaha; atau

b. Memiliki hasil penjualan tahunan lebih dari Rp 2.500.000.000,00 (dua miliar lima ratus juta rupiah) sampai dengan paling banyak Rp50.000.000.000,00 (lima puluh miliar rupiah).

Menurut Kuncoro dalam Endang dkk, 2018 Karakteristik Usaha Kecil adalah tidak adanya pembagian tugas yang jelas antara bidang administrasi dan operasi, rendahnya akses industri kecil terhadap lembaga kredit, belum dipunyainya status badan hukum dan hammpir semuanya bergerak pada usaha industri makanan, minuman dna tembakau. Kemudian dalam pengembangan usaha kecil dan koperasi sebagai basis ekonomi kerakyatan merupakan salah satu langkah strategik yang perlu ditindaklanjutin. Strategi pemberdayaan yang tepat meliputi:

1. Aspek managerial meliputi peningkatan produktivitas, pemasaran dan pengembangan sumber daya manusia,

2. Aspek pemodalan,

3. Mengembangan pola kemitraan,

4. Mengembangkan sentra industry kecil dan pembinaan untuk bidang usaha dan daerah tertentu lewat kelompok usaha bersama dan koperasi industry kecil dan kerajinan. 


\section{Bagan dan Road Map}

Bagan dan Road Map dalam penelitian ini adalah :

Bagan Penelitian

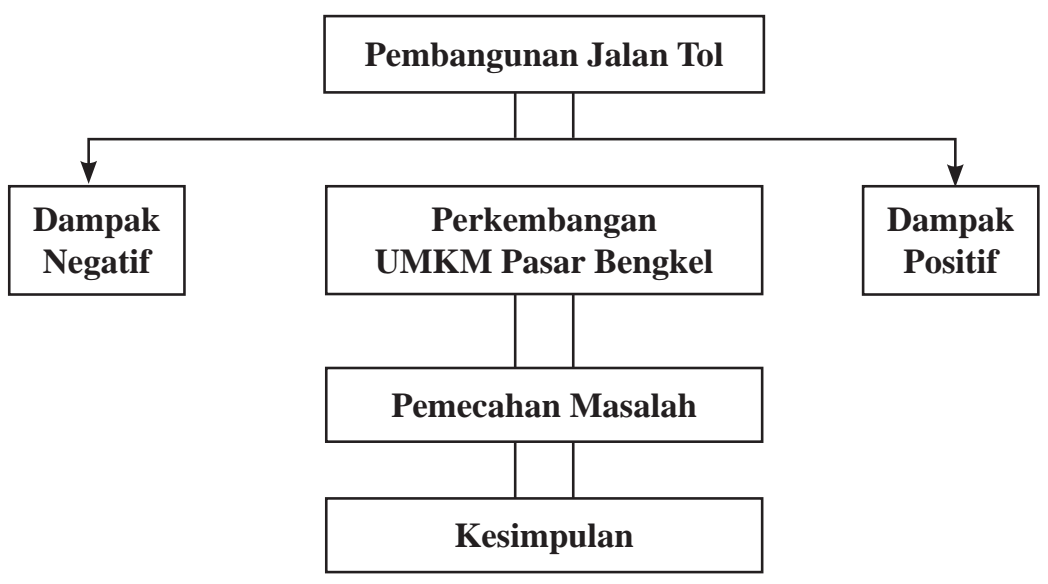

Gambar 1. Bagan Penelitian, 2018

ROADMAP:
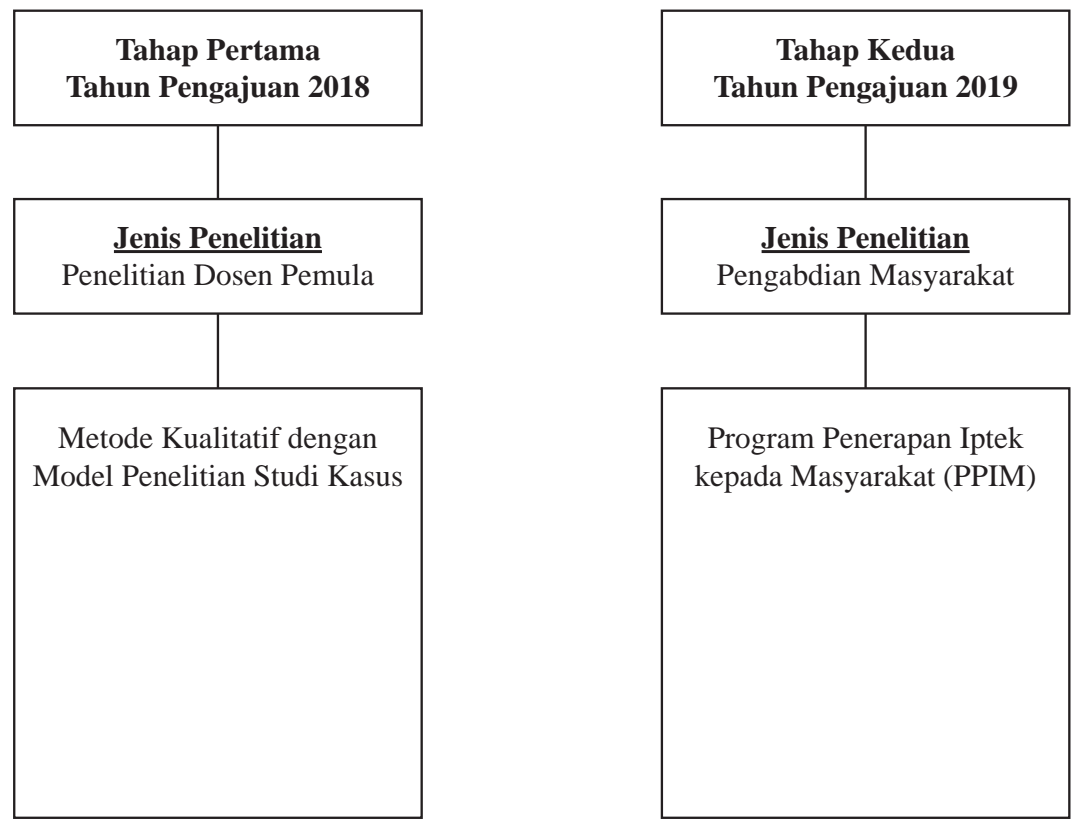

Gambar 2. Roadmap Penelitian 2018

\section{Metodologi Penelitian}

Data yang hendak dikumpulkan adalah Analisis Dampak Pembangunan Jalan Tol MedanTebing tinggi terhadap Usaha Mikro Kecil dan Menengah yang ada di Pasar Bengkel Kabupaten Serdang Bedagai. dari ungkapan konsep tersebut jelas bahwa yang dikehendaki adalah suatu informasi dalam bentuk deskripsi. 
Jenis Penelitian adalah Penelitian Kasus (Case Study), menurut Maxfield dalam Sinulingga 2011: 27 bahwa Penelitian kasus adalah suatu jenis penelitian tentang status subjek penelitian yang berkenaan dengan suatu frase spesifik dari keseluruhan personalitas.

Dan metode penelitian yang dipakai adalah Metode kualitatif, menurut Sugiyono 2010: 8. Metode Kualitatif adalah metode penelitian yang berlandaskan pada filsafat postpositivisme, digunakan untuk meneliti pada kondisi obyek yang alamiah, (sebagai lawannya adalah eksperimen) dimana peneliti adalah sebagai instrumen kunci, teknik pengumpulan data secara triangulasin(gabungan), analisis data bersifat induktif/kualitatif, dan hasil penelitian kualitatif lebih menekankan makna dari pada generalisasi.

Sifat penelitiannya adalah deskriptif analitis berupa kata-kata tertulis atau lisan dari orangorang. Pada pendekatan ini , peneliti membuat suatu gambaran kompleks, laporan terperinci, dan melakukan studi pada situasi yang dialami. Sedarmayanti dan Syarifuddin (2011:33) menjelaskan bahwa penelitian deskriptif bertujuan dalam pencarian fakta status kelompok manusia, suatu objek, suatu kondisi, ataupun suatu peristiwa pada masa sekarang dengan interprestasi yang tepat. Menurut Sinulingga 2011 : 165 Data Primer adalah data yang diperoleh dengan cara mencari/ mengali secara langsung dari sumbernya oleh peneliti bersangkutan. Data sekunder adalah data yang telah dikumpulkan dan diolah oleh pihak lain sehingga tidak perlu lagi digali/dicari oleh peneliti bersangkutan.

\section{Tahapan Alir Penelitian}

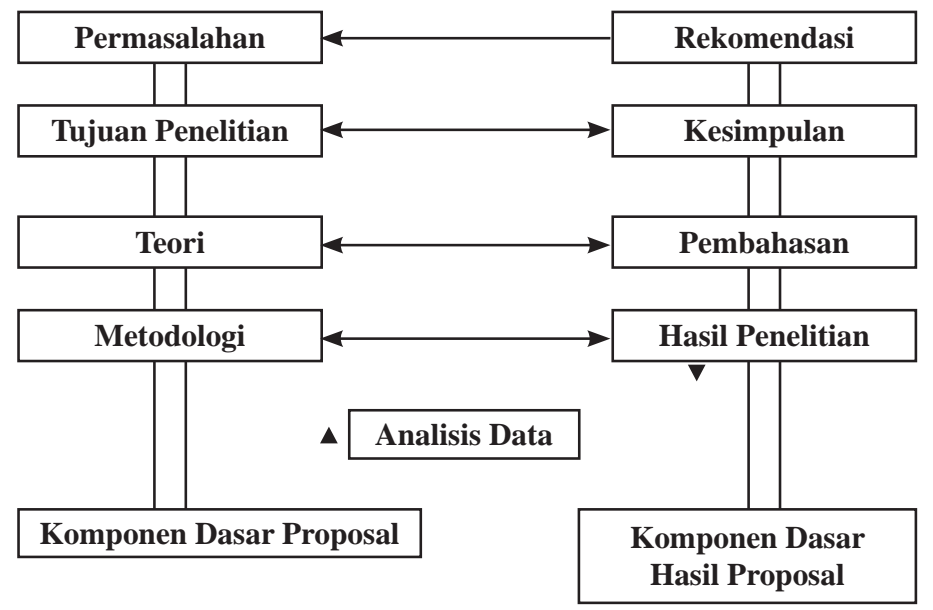

Gambar 3. Diagram Alir Penelitian, 2018

\section{Hasil dan Pembahasan}

Menurut Tambunan (2012 : 5) UMKM tidak saja berbeda dengan Usaha Besar (UB), tetapi di dalam kelompok UMKM itu sendiri terdapat perbedaan karakteristik antara Usaha Mikro (UMI) dengan Usaha Kecil (UK) dan Usaha Menengah (UM) dalam sejumlah aspek yang mudah dilihat sehari-hari di NSB, termasuk Indonesia. 
Tabel 1. Karakteristik-karakteristik Utama UMI, UK, dan UM

\begin{tabular}{|c|c|c|c|c|}
\hline No & Aspek & UMI & UK & UM \\
\hline 1. & Formalitas & $\begin{array}{l}\text { Beroperasi di sector } \\
\text { informal; usaha tidak } \\
\text { terdaftar; tidak/jarang bayar } \\
\text { pajak }\end{array}$ & $\begin{array}{l}\text { Beberapa beroperasi di } \\
\text { sector formal; beberapa } \\
\text { tidak tedaftar; sedikit } \\
\text { yang bayar pajak }\end{array}$ & $\begin{array}{l}\text { Semua di sector } \\
\text { formal; terdaftar dan } \\
\text { bayar pajak }\end{array}$ \\
\hline 2. & $\begin{array}{l}\text { Organisasi \& } \\
\text { manajemen }\end{array}$ & $\begin{array}{l}\text { Dijalankan oleh pemilik; } \\
\text { tidak menerapkan } \\
\text { pembagian tenaga kerja } \\
\text { internal (ILD), manajemen } \\
\text { \& struktur organisasi } \\
\text { formal (MOF) system } \\
\text { pembukuan formal (ACS) }\end{array}$ & $\begin{array}{l}\text { Dijalankan oleh pemilik; } \\
\text { tidak ada ILD, MOF, } \\
\text { ACS }\end{array}$ & $\begin{array}{l}\text { Banyak yang } \\
\text { mengerjakan manajer } \\
\text { professional dan } \\
\text { menerapkan ILD, } \\
\text { MOF, ACS }\end{array}$ \\
\hline 3. & $\begin{array}{l}\text { Sifat dari } \\
\text { kesempatan } \\
\text { kerja }\end{array}$ & $\begin{array}{l}\text { Kebanyakan mengunakan } \\
\text { anggota-anggota keluarga } \\
\text { tidak dibayar }\end{array}$ & $\begin{array}{l}\text { Beberapa memakai } \\
\text { tenaga kerja (TK) yang } \\
\text { digaji }\end{array}$ & $\begin{array}{l}\text { - Semua memakai TK } \\
\text { digaji } \\
\text { - Semua memiliki } \\
\text { system perekrutan } \\
\text { formal }\end{array}$ \\
\hline 4. & $\begin{array}{l}\text { Pola/sifat } \\
\text { dari proses } \\
\text { produksi }\end{array}$ & $\begin{array}{l}\text { Derajat mekanisasi sangat } \\
\text { rendah/umumnya manual; } \\
\text { tingkat teknologi sangat } \\
\text { rendah }\end{array}$ & $\begin{array}{l}\text { Beberapa memakai } \\
\text { mesin-mesin terbaru }\end{array}$ & $\begin{array}{l}\text { Banyak yang } \\
\text { mempunyai derajat } \\
\text { mekanisasi yang } \\
\text { tinggi/mempunyai } \\
\text { akses terhadap } \\
\text { teknologi. }\end{array}$ \\
\hline 5. & $\begin{array}{l}\text { Orientasi } \\
\text { pasar }\end{array}$ & $\begin{array}{l}\text { Umumnya menjual ke } \\
\text { pasar local untuk kelompok } \\
\text { berpendapatan rendah }\end{array}$ & $\begin{array}{l}\text { Banyak yang menjual } \\
\text { ke pasar domestic dan } \\
\text { ekspor, dan melayani } \\
\text { kelas menengah ke atas }\end{array}$ & $\begin{array}{l}\text { Semua menjual ke } \\
\text { pasar domsetik dan } \\
\text { banyak yang ekspor, } \\
\text { dan melayani kelas } \\
\text { menengah ke atas }\end{array}$ \\
\hline 6. & $\begin{array}{l}\text { Profil } \\
\text { ekonomi \& } \\
\text { social dari } \\
\text { pemilik usaha }\end{array}$ & $\begin{array}{l}\text { Pendidikan rendah \& dari } \\
\text { rumah tangga (RT) miskin; } \\
\text { motivasi utama survival }\end{array}$ & $\begin{array}{l}\text { Banyak berpendidikan } \\
\text { baik \& dari RT non } \\
\text { miskin; banyak yang } \\
\text { bermotivasi bisnis/ } \\
\text { mencari profit }\end{array}$ & $\begin{array}{l}\text { Sebagian besar } \\
\text { berpendidikan baik } \\
\text { dan dari RT maksmur; } \\
\text { motivasi utama: profit }\end{array}$ \\
\hline 7. & $\begin{array}{l}\text { Sumber- } \\
\text { sumber dari } \\
\text { bahan baku } \\
\text { modal }\end{array}$ & $\begin{array}{l}\text { Kebanyakan pakai bahan } \\
\text { baku local dan uang sendiri }\end{array}$ & $\begin{array}{l}\text { Beberapa memakai } \\
\text { bahan baku impor dan } \\
\text { mempunyai akses ke } \\
\text { kredit formal }\end{array}$ & $\begin{array}{l}\text { Banyak yang memakai } \\
\text { bahan baku impor dan } \\
\text { mempunyai akses ke } \\
\text { kredit formal }\end{array}$ \\
\hline 8. & $\begin{array}{l}\text { Hubungan- } \\
\text { hubungan } \\
\text { eksternal }\end{array}$ & $\begin{array}{l}\text { Kebanyakan tidak } \\
\text { mempunyai akses } \\
\text { ke program-program } \\
\text { pemerintah dan tidak punya } \\
\text { hubungan-hubungan bisnis } \\
\text { dengan UB }\end{array}$ & $\begin{array}{l}\text { Banyak yang punya } \\
\text { akses ke program- } \\
\text { program pemerintah } \\
\text { dan [unya hubungan } \\
\text { hubungan-hubungan } \\
\text { bisnis dengan UB } \\
\text { (termasuk PMA) }\end{array}$ & $\begin{array}{l}\text { Sebagian besar punya } \\
\text { akses ke p[program- } \\
\text { program pemerintah } \\
\text { dan banyak yang } \\
\text { punya hubungan- } \\
\text { hubungan bisnis } \\
\text { dengan UB (termasuk } \\
\text { PMA) }\end{array}$ \\
\hline 9. & $\begin{array}{l}\text { Wanita } \\
\text { penguasah }\end{array}$ & $\begin{array}{l}\text { Rasio dari wanita terhadap } \\
\text { pria sebagai pengusaha } \\
\text { sangat tinggi }\end{array}$ & $\begin{array}{l}\text { Rasio dari wanita } \\
\text { terhadap pria sebagai } \\
\text { pengusaha cukup tinggi }\end{array}$ & $\begin{array}{l}\text { Rasio dari wanita } \\
\text { terhadap pria sebagai } \\
\text { pengusaha sangat } \\
\text { rendah }\end{array}$ \\
\hline
\end{tabular}




\section{Dampak Negatif}

Pembangunan jalan tol merupakan salah satu solusi dari pendistribusian baik barang dan manusia dengan cara mudah dan efektif dari sisi waktu dan jarak. Pembangunan jalan tol merupakan salah satu solusi yang ditawarkan oleh pemerintah sekarang ini untuk mempercepat pertumbuhan di suatu daerah dan melakukan perataan pembangunan di setiap daerah. Pembangunan jalan tol akan memberikan kontribusi yang negatif ketika pembangunan itu dilakukan dengan cara tidak mementingkan beberapa unsur, baik itu dari unsur masyarakat maupun lingkungan. Dampak negatif ini akan membuat pertumbuhan di beberapa pihak akan terhambat, sehingga sedikit banyaknya akan mempengaruhi pembangunan secara keseluruhan.

Dalam penelitian ini, objek penelitian diambil secara random atau acak, dimana para responden merupakan pemilik took yang ada di sekitaran pasar bengkel, ada pun banyaknya responden dalam penelitian ini adalah sebanyak 36 toko yang masih aktif berjualan. Karena berdasarkan studi di lapangan, ternyata sudah banyak yang tutup toko yang tutup di karenakan dampak dari pembangunan jaln tol Medan- Tebing Tinggi.
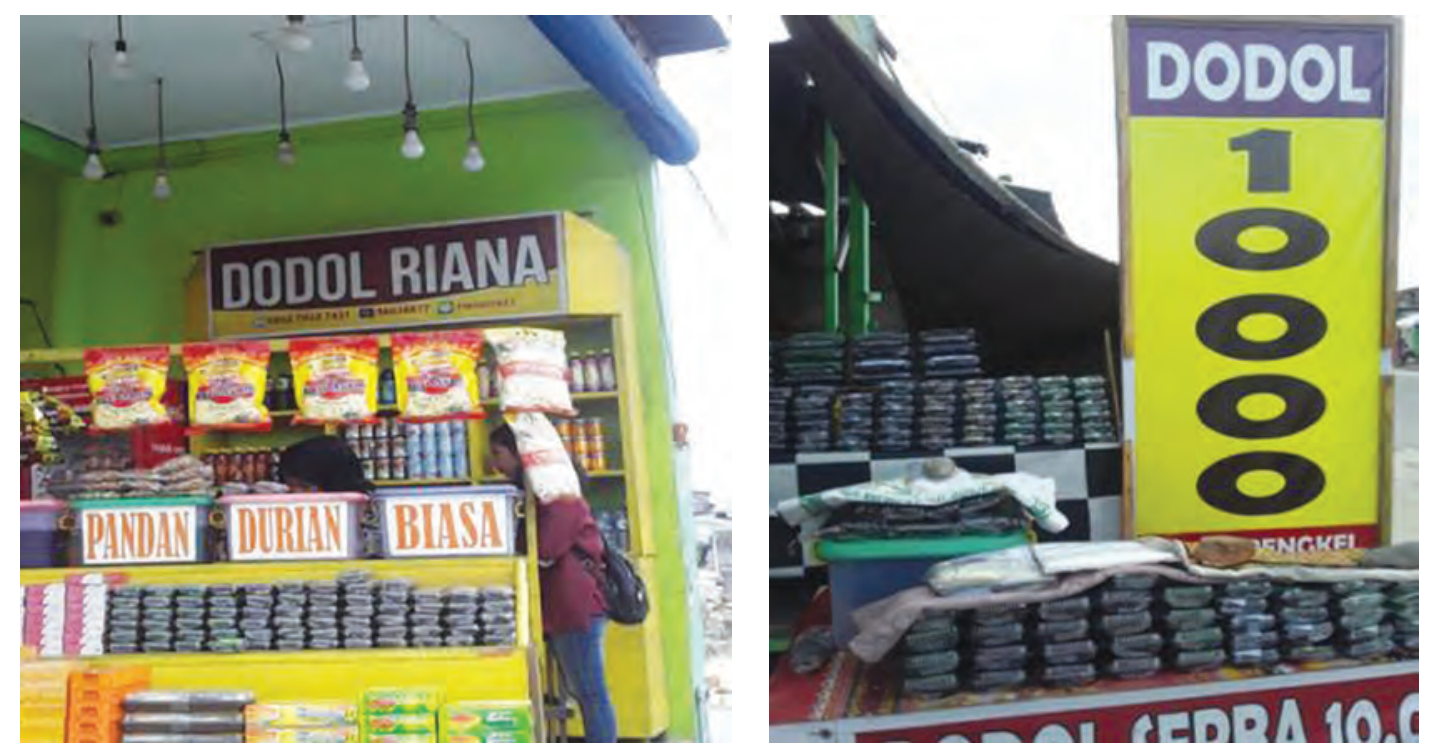

\section{Kategori Pendapatan}

Penilaian akan dilakukan dengan melihat pertumbuhan pendapatan dari toko-toko yang ada di sekitaran pasar bengkel. Penilaian pendapatan terdiri dari 4 kategori, yaitu :

1. Kategori I memiliki pendapatan Rp. 50.000.000 sampai Rp. 40.000.000.

2. Kategori II memiliki pendapatan Rp. 39.000.000 sampai Rp. 30.000.000.

3. Kategori III memiliki pendapatan Rp. 29.000.000 sampai Rp. 20.000.000

4. Kategori IV memiliki pendapatan Rp. 19.000 .000 sampai Rp. 0 


\section{Grafik 1. Pendapatan Sebelum Ada Jalan Tol}

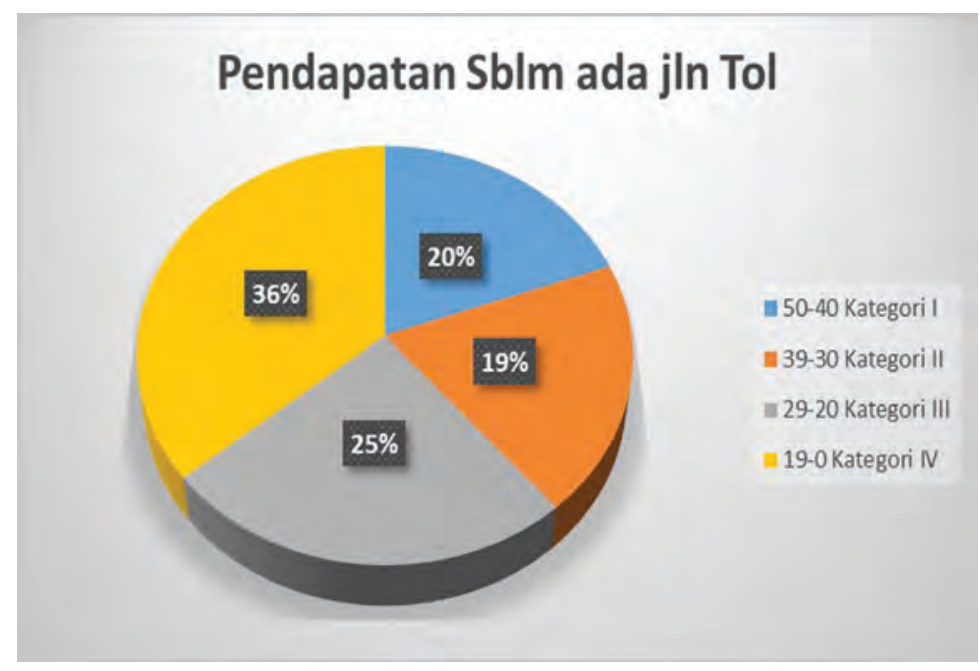

Sumber : data olah, 2019

Dari Grafik 1 dapat dilihat bahwa pendapatan dari 36 toko yang ada di sekitaran pasar bengkel sebelum ada jalan tol yaitu kategori I ada sebesar $20 \%$ atau sebanyak 7 toko, sedangkan kategori II sebesar 19\% atau sebanyak 7 toko, dan kategori III sebesar 25\% atau sebanyak 9 toko, kemudian kategori IV sebesar 36\% atau sebanyak 13 toko.

\section{Grafik 2. Pendapatan Setelah Ada Jalan Tol}

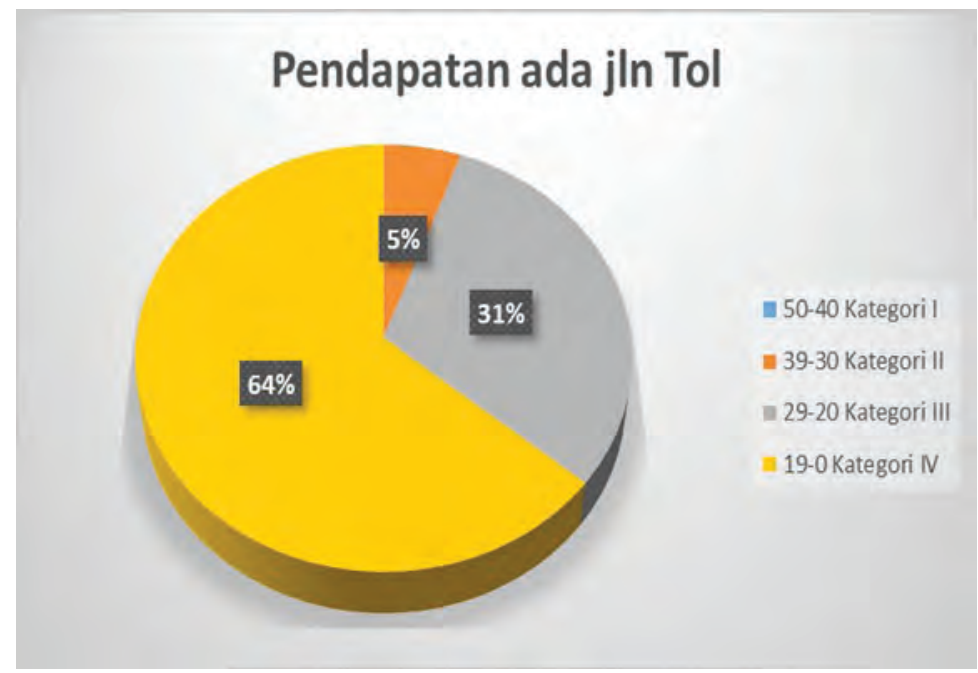

Sumber : data diolah, 2019

Dari Grafik 2 dapat dilihat bahwa pendapatan dari 36 toko yang ada di sekitaran pasar bengkel sesudah ada jalan tol yaitu kategori I ada sebesar $0 \%$ atau tidak ada toko yang mencapai kategori 1 pendapatannya, sedangkan kategori II sebesar 5\% atau sebanyak 2 toko, dan kategori III sebesar 31\% atau sebanyak 11 toko, kemudian kategori IV sebesar 64\% atau sebanyak 23 toko. 


\section{Kategori Tenaga Kerja}

Tenaga kerja merupakan salah satu unsur utama dalam sebuah usaha dalam menjamin terlaksananya suatu proses usaha itu, pemerintah selalu berusaha untuk menguranggi pengangguran dengan membuka lapangan kerja di setiap lini bisnis usaha. Peran pemerintah itu dapat dirasakan baik secara langsung dan secara tidak langsung, dampak dari pembangunan jalan tol MedanTebing Tinggi sangat berpengaruh sekali kepada penguranggan dan penambahan pengangguran, hal itu dengan dapat dilihat dari hasil observasi lapangan :



Tabel 2. Jumlah Karyawan dari 36 Toko

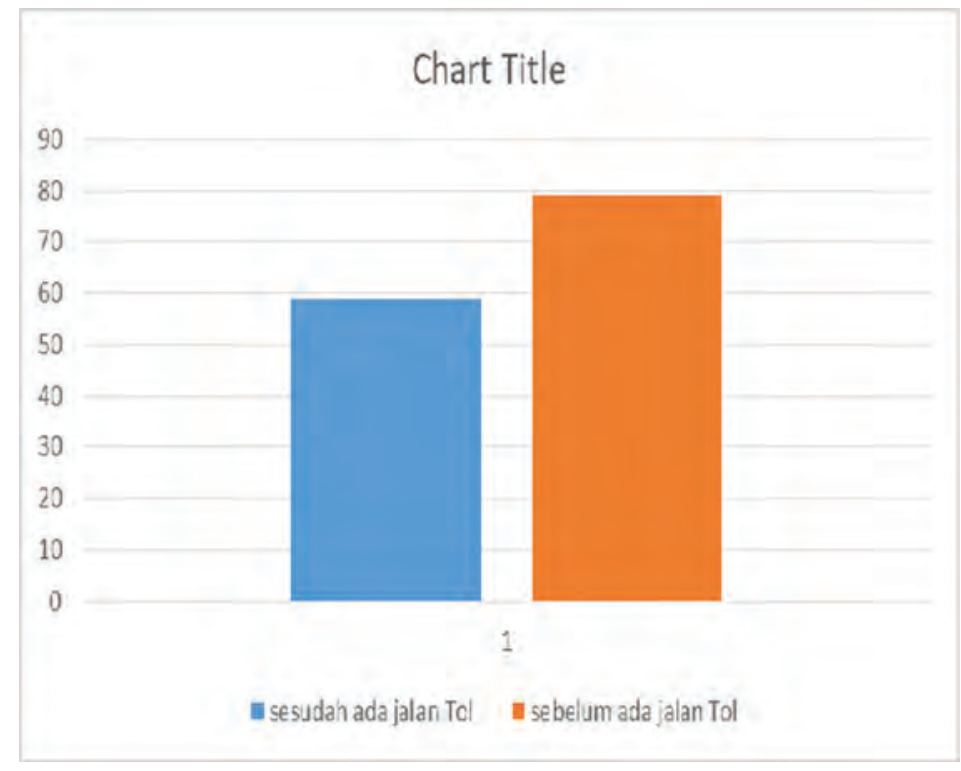

Sumber : data diolah, 2019

Dari Tabel 2 dapat kita lihat bagaimana pertumbuhan jumlah karyawan atau tenaga kerja yang ada di 36 toko yang ada di sekitaran pasar bengkel, pada saat belum ada jalan tol ada sebanyak 79 orang karyawan sedangkan sesudah ada jalan tol terjadi pengurangan totalnya menjadi 59 orang. dampak dari pembangunan jalan tol sangat terasa dengan terjadinya pengurangan tenaga kerja yang ada di toko-toko tersebut. 


\section{Kategori Pendapat Asli Daerah}

Pendapatan Asli Daerah, selanjutnya disebut PAD adalah pendapatan yang diperoleh daerah yang dipungut berdasarkan Peraturan Daerah sesuai dengan peraturan perundang undangan (UU Nomor 33 Tahun 2004 Pasal 1, ayat 18). Sumber Pendapatan Asli Daerah, diperoleh dari :

a. Pajak Daerah

Pajak daerah merupakan salah satu komponen pendapatan asli daerah yang diperoleh dari orang pribadi atau badan. Mardiasmo (2009) menyatakan pajak daerah adalah iuran wajib yang dilakukan oleh orang pribadi atau badan kepada daerah tanpa imbalan langsung yang seimbang, yang dapat dipaksakan berdasarkan peraturan perundang-undangan yang berlaku, yang digunakan untuk membiayai penyelenggaraan pemerintah daerah dan pembangunan daerah.

b. Retribusi Daerah

Retribusi daerah, yang selanjutnya disebut retribusi, adalah pungutan Daerah sebagai pembayaran atas jasa atau pemberian izin tertentu yang khusus disediakan dan/atau diberikan oleh Pemerintah Daerah untuk kepentingan orang pribadi atau badan.

c. Hasil pengelolaan kekayaan daerah yang dipisahkan

Kontribusi tersebut dapat berupa deviden yang dibayarkan kepada daerah atau juga dengan memanfaatkan kekayaan daerah seperti penyewaan tanah dan bangunan daerah yang dapat mendatangkan tambahan bagi penerimaan daerah. Jenis pendapatan yang tergolong dari hasil pengelolaan kekayaan daerah yang dipisahkan ini antara lain, bagian laba, deviden.

d. Lain-lain PAD yang sah

Yang termasuk dalam penerimaan lain-lain PAD yang sah antara lain : hasil penjualan barang milik daerah, penjualan barang-barang bekas, cicilan kendaraan bermotor, cicilan rumah dinas, penerimaan atas kekayaan daerah, sumbangan pihak ketiga, penerimaan jasa giro (kas daerah) dan lain-lain. Rumusnya menghitung pendapatan asli daerah adalah Pajak Daerah + Retribusi Daerah + Hasil Pengelolaan Kekayaan Daerah yang Dipisahkan + Lain - lain PAD yang Sah.

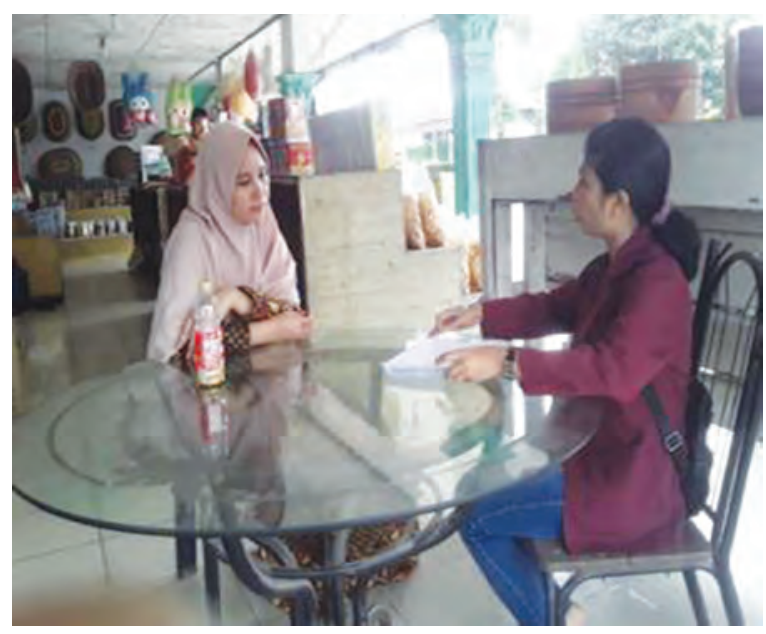


Tabel 3.

\section{Pendapatan Asli Daerah (Restribusi) Kabupaten Serdang Bedagai tahun 2012,2013,2014 dan 2017}

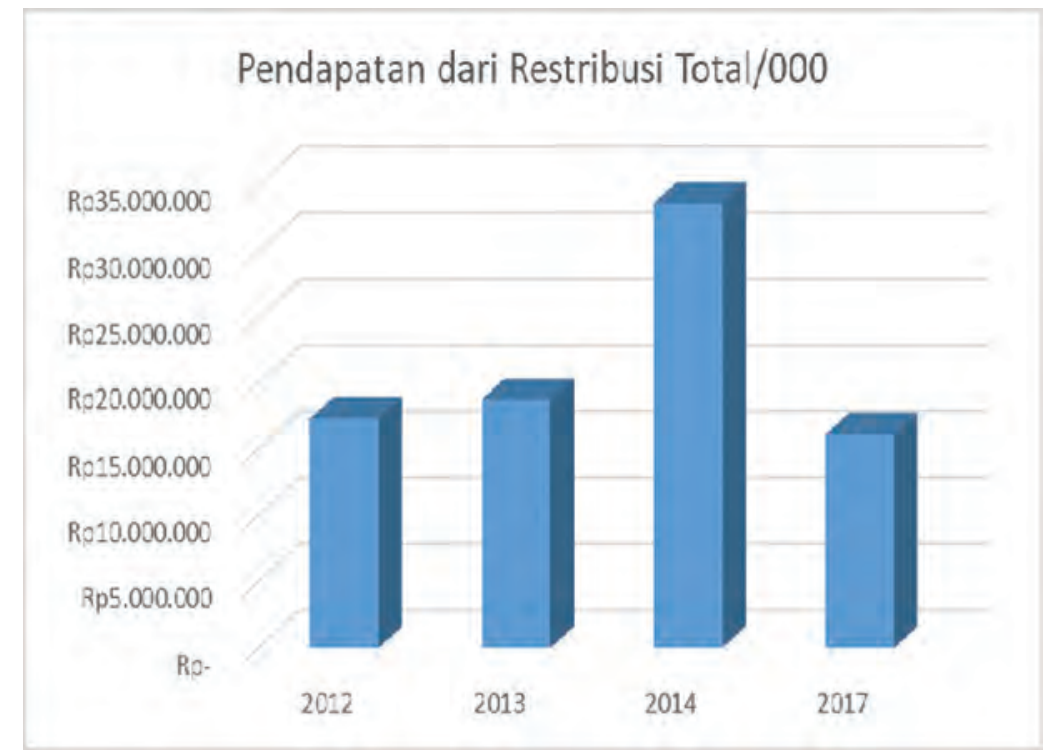

Sumber : BPS, 2019

Jalan tol ruas Parbarakan-Sei Rampah sepanjang 41,7 kilometer diresmikan oleh Presiden Joko Widodo pada 13 Oktober 2017. Maka sejak awal tahun 2017 para pengusaha UMKM di sekitaran pasar bengkel sudah merasakan dampak yang terjadi. Yaitu pengurangan pelanggan yang singgah untuk membeli jajanan, minuman dan lainnya. Dari Tabel 3 dapat kita lihat pendapatan asli daerah kabupaten serdang bedagai sejak tahun 2012 sampai 2014 terjadi peningkatan sebesar Rp17.273.636.000 pada tahun 2012 dan pada tahun 2013 sebesar Rp18.698.686.000 dan pada tahun 2014 sebesar Rp33.547.554.000. namum sejak pembangunan jalan tol ruas ParbarakaSei Rampah terjadi penurunan signifikan yaitu sebesar Rp.16.087.440.000 hal ini dikarenakan turunnya pendapatan distribusi dari UMKM pasar bengkel.

\section{Dampak Positif}

Berdasarkan kuesioner terbuka yang disebar, maka didapat juga unsur positif dari pembangunan jalan tol Medan- Tebing Tinggi. Adapun unsur positif itu meliputi:

1. Polusi udara yang berkurang

2. Tidak ada kemacetan

3. Terbukanya peluang penjualan secara online

4. Pesaing berkurang karena banyak yang tutup.

Pembangunan jalan tol Medan-Tebing Tinggi sangat memiliki dampak yang baik dan tidak baik bagi masyarakat yang tinggal di sekitaran jalan lintas sumatera kabupaten serdang berdagai. Pembangunan ini akan mempermudah laju distribusi barang dan manusia namum hal ini juga mempengaruhi ekonomi masyarakat yang dihubungkan oleh jalan tol tersebut.

\section{Pembahasan}

Pembangunan jalan tol Medan-Tebing Tinggi merupakan salah satu proyek strategis pemerintah presiden Jokowi, pembangunan ini diharapkan akan menjadi Jalan Tol Trans Sumatera yang akan 
menghubungkan pulau sumatera dari sabang sampai lampung. alam pembangunannya, jalan tol ini terbagi dalam dua seksi, yaitu Seksi I (Medan-Perbarakan-Kualanamu) sepanjang 17,80 km dan Seksi II (Perbarakan-Tebing Tinggi) sepanjang 44 km. Jalan tol ini memiliki 2x2 lajur pada tahap awal dan 2x3 lajur pada tahap akhir dengan kecepatan rencana 100 km/jam.Peletakan batu pertama tanda dimulainya konstruksi dilaksanakan pada 23 September 2014.

Pasar bengkel merupakan salah satu nadi perekonomian dari masyarakat kabupaten Serdang Bedagai, pasar bengkel sudah ada sejak tahun 1970an dimana letak pasar bengkel ini berada di sekitaran ajalan lintas sumatera. Pasar bengkel menjadi primadona persinggahan untuk istirahat baik itu makan dan minum bagi pengendara yang berasal dari kota Medan sekitarnya yang ingin pergi ke arah sumatera bagian timur atau sebaliknya.

Dampak pembangunan jalan tol Medan- Tebing Tinggi sangat terasa bagi masayarakat UMKM yang ada di sekitaran Pasar Bengkel. Dampak itu bukan hanya terkena pada masyarakat namun pemerintah daerah juga, dampak pembangunan jalan tol ini terbagi dalam :

1. Pendapatan per kapita dari UMKM pasar bengkel yang menurun drastis sampai 50\% pendapatan per bulan.

2. Tenaga kerja yang dipekerjakan oleh pihak UMKM yang semakin sedikit, dimana tadinya bias mempekerjakan 2 sampai 5 orang per toko maka sekarang hanya mampu mepekerjakan 1 sampai 2 orang saja.

3. Pendapatan Asli Daerah yang berasal dari restribusi, terjadi penurun signifikan sejak dibangunnya jalan tol.

4. Seedangkan dampak positif yang dirasakan oleh masayarakat pasar bengkel yaitu tidak terjadinya kemacetan dan polusi udara yang berkurang.

\section{Simpulan}

Dalam pembangunan jalan tol, baiknya pemerintah pusata dan daerah harus terlebih dahulu melihat dampak yang dirasakan oleh masyarakat setempat ketika terjadi pembangunan, pembangunan jalan tol harus terlebih dahulu dilakukan suatu kajian yang menyangkut ekonomi kerakyatan, sehingga tidak mempeengaruhi kehidupan ekonomi masyarakat setempat. Dari hasil penelitian ini dapat disimpulkan bahwa pembangunan jalan tol Medan-Tebing Tinggi sangat berdampak negatif kepada masayarakat pelaku UMKM di sekitaran Pasar Bengkel.

\section{Daftar Pustaka}

Purwaningsih, E. Huda, N. Muslik, H. Annisariza, N. 2018. UMKM Aspek Hukum dan Manajemen Pemasaran Produk. Malang: Empat dua.

Sinulingga, S. 2011. Metode Penelitian. Medan: USU Press.

Sugiyono. 2010. Metode Penelitian Kuantitatif, kualitatif dan R\&D. Bandung: Alfabeta.

Sedarmayanti, Syarfudin. 2011. Metodologi Penelitian. Bandung: Mandar Maju.

Tambunan, T. 2012. Usaha Mikro Kecil dan Menengah di Indonesia. Jakarta: LP3ES.

Undang- Undang Nomor 20 Tahun 2008 tentang Usaha Mikro, Kecil dan Menengah (UMKM):

Undang - Undang Nomor 33 Tahun 2004 Pasal 1, ayat 18 tentang Pendapatan Asli daerah 